\title{
ECONOMIC IMPLICATIONS OF \\ CHANGING SHARE OWNERSHIP
}

Benjamin M. Friedman

Working Paper No. 5141

\section{NATIONAL BUREAU OF ECONOMIC RESEARCH 1050 Massachusetts Avenue \\ Cambridge, MA 02138 \\ June 1995}

This paper is part of NBER's research programs in Asset Pricing and Monetary Economics. Any opinions expressed are those of the author and not those of the National Bureau of Economic Research.

(C) 1995 by Benjamin M. Friedman. All rights reserved. Short sections of text, not to exceed two paragraphs, may be quoted without explicit permission provided that full credit, including () notice, is given to the source. 


\title{
ECONOMIC IMPLICATIONS OF
}

\section{CHANGING SHARE OWNERSHIP}

\begin{abstract}
Institutional investors, including especially pension funds and mutual funds, are steadily replacing individuals as owners of equity shares in the United States. Forty years ago individual investors owned $90 \%$ of all equity shares outstanding. Today the individually owned share is just $50 \%$.

The arguments and evidence surveyed in this paper suggest four ways in which this shift in share ownership could affect the functioning of the equity market: (1) Increasing institutional ownership could either enhance or impair the market's ability to provide equity financing for emerging growth companies. (2) Increasing institutional ownership, especially in the form of open-end mutual funds, has probably increased the market's volatility in the context of occasional large price movements. (3) The increasing prevalence of defined contribution (as opposed to defined benefit) pension plans, and especially of 401-k plans, has probably resulted in an increased market price of risk. (4) Increasing institutional ownership has facilitated a greater role for shareholders in the governance of U.S. corporate business, and correspondingly reduced the independence of corporate managements.
\end{abstract}

Benjamin M. Friedman

Department of Economics

Harvard University

Littauer Center 127

Cambridge, MA 02138

and NBER 
Revised

March, 1995

\section{ECONOMIC IMPLICATIONS OF CHANGING SHARE OWNERSHIP}

\section{Benjamin M. Friedman* \\ Harvard University}

Who owns what is a subject that inevitably attracts close attention. In the case of publicly traded equity securities, the question is of interest for more than the usual idle reasons.

The stock market bears a special responsibility in any advanced economy that functions in large part on private ownership and initiative. It provides a vehicle for transferring spending power from savers to investors, and it establishes relative prices that serve as signals and incentives to guide allocations that rely on, but take place apart from, the market mechanism itself. At the same time, the transfers that the stock market effects and the relative prices it establishes are the result of decisions taken by real people -- people who own stocks, and still other people appointed to act in their place. If changing the cast of characters, or the way in which they play their appointed roles, alters the market's performance of its basic functions, then those changes can also alter the quantity and composition of the capital formation the economy undertakes, or the ways in which that capital is deployed. What is ultimately at issue, therefore, is the economy's ability to achieve advancing productivity and competitiveness over time, and hence to deliver an advancing standard of living to the society of which it is a part.

While patterns of share ownership in the United States are almost always changing in one way or another, 1994 marked a watershed of sorts (see 
Table 1). For the first time on record, the proportion of shares owned by households (including personal trusts) fell to just 508. Institutional investors -. pension funds, mutual funds, insurance companies, and so on -- now hold the majority of all equity shares outstanding. By contrast, as recently as forty years ago these institutions together held less than 108 of the outstanding shares, and individuals more than 908.1

Progressive institutionalization has been the dominant ongoing change in U.S. share ownership since World War II, but it is not the only such change. Increasing globalization of financial markets has extended to equities as well, and foreign investors now hold nearly $6 \%$ of all American-issued stocks (up from barely 28 just a quarter-century ago). Much of the expanded institutional ownership has been in tax-exempt vehicles, especially corporate or government-sponsored pensions, but the advent of Keogh Plans and Individual Retirement Accounts has also allowed individuals to hold in tax-exempt form a growing fraction of the shares they continue to own directly. ${ }^{2}$ Finally, just in the last few years the increasing popularity of defined contribution plans within the private pension sector represents a potential reversal of the secular trend toward institutionalization, in the sense that under this kind of arrangement some important dimensions of ownership, like asset allocation at the gross level, typically revert to the individual beneficiary. ${ }^{3}$

The object of this paper is to consider how such changes over time in patterns of U.S. share ownership have affected, or are likely to affect, the stock market's ability to play the important role assigned to it in the American economic system. For purposes of this paper, the central element in this role is the provision of capital to American business and the establishment of relative prices to guide the allocation of that capital (and 
TABLE 1

PERCENTAGE OUNFRSUIP OF $\underline{\text { OU. }}$. F.QUITIES, $1950-1994$

\begin{tabular}{|c|c|c|c|c|c|c|}
\hline & 1950 & 1960 & 1970 & 1980 & 1990 & 1294 \\
\hline Households & & & & $60.9 \%$ & $48.6 \%$ & $48.2 \%$ \\
\hline Bank-Managed Personal Trusts & $91.6 \%$ & $87.7 \%$ & $80.4 \%$ & 7.4 & 5.4 & 2.6 \\
\hline Private Pension Funds & 0.8 & 3.7 & 7.4 & 14.6 & 18.6 & 17.3 \\
\hline Open-End Mutual Funds & 2.0 & 3.3 & 4.4 & 2.8 & 6.6 & 12.2 \\
\hline State-Local Government Retirement Funds & 0.0 & 0.1 & 1.1 & 2.9 & 8.4 & 8.6 \\
\hline Insurance Companies & 3.2 & 2.8 & 3.2 & 5.1 & 5.0 & 4.4 \\
\hline All Fore1gn Holders & 2.0 & 2.1 & 3.0 & 4.2 & 6.3 & 5.6 \\
\hline All Other Holders & 0.5 & 0.4 & 0.5 & 2.2 & 1.1 & 1.2 \\
\hline Total & 100.0 & 100.0 & 100.0 & 100.0 & 100.0 & 100.0 \\
\hline
\end{tabular}

NOTES: Values shown are year-end dollar holdings, at market prices, as percentages of corresponding total year-end shares outstanding.

Detafl may not add to totals because of rounding.

SOURE: Board of Governors of the Federal Reserve System, Flow-of-Funds Accounts. 
business decision making more generally). The overall approach taken here is frankly speculative and inquiring. The object is to stimulate thought on some important issues by raising questions. The paper does little to provide answers.

Section I provides the conceptual framework that underlies the discussion of specific issues throughout the paper by reviewing, at a fairly fundamental level, why changing patterns of share ownership might be expected to matter in the first place. Sections II-V take up four specific questions: how the progressive institutionalization of share ownership affects the market's ability to finance new companies (II), how it affects market volatility (III), what particular implications follow from the trend away from defined benefit pension plans to define contribution plans (IV), and what all this means for the role of share owners in corporate governance (V). Section VI briefly concludes.

\section{Basic Relationships: Why the Pattern of Share Ownership Matters}

Who owns the shares -- and, when ownership and decision making are separate, who decides what to buy or sell -- affects the stock market's performance of its economic function in two basic ways.

First, the outcomes established in any market populated by heterogeneous participants reflects the average set of bellefs, and the average set of preferences, that those participants bring to bear, in each case weighted by their respective command over resources. ${ }^{4}$ (In the stock market context, all Investors are definitely not created equal.) In many respects, if not most, differences of beliefs and preferences are distributed purely at random among investors. Some people believe the electric car is the way of the future; others think the notion is silly on its face. Some people blanch at the 
prospect of any losses whatever in their portfolios; others positively enjoy the thrill of assuming major risks. When such differences are purely random, even major changes in share ownership need not imply changes in market outcomes.

By contrast, when investors' beliefs or preferences differ systematically - as they plausibly do, especially across major distinctions like individuals versus institutions - - then changes in the pattern of share ownership across those fault lines increase the weight placed on the beliefs and preferences of some, and correspondingly reduce the weight placed on others', in making up the governing market-wide "average." And when market-average beliefs or preferences change, so too do market outcomes.

Second, in addition to the more basic issue of investors' beliefs and preferences, the structure of market decision making can also affect market outcomes. Actions taken by agents acting in others' behalf do not always mirror actions that would be taken in the same circumstance by principals acting for themselves. ${ }^{5}$ Funneling individual stock holdings through mutual funds, with professional managers responsible for either stock selection or market timing, may introduce any of a number of biases into the resulting market outcomes. For example, professional managers may be better informed than individual investors, but they may also restrict their attention to a more limited scope of potential investments. Conversely, economies of scale may plausibly make managers of pooled assets more readily able to undertake novel kinds of transactions and monitoring arrangements, and hence willing to entertain a broader range of potential investment activities. ${ }^{6}$

In addition, to the extent that the size of the market aggregate of invested capital is fixed at any given time, collecting it into pooled forms 
necessarily means concentrating the decision making process into fewer hands. And to the extent that the appointed decision makers do not act independently -- for example, because of the nature of competition within their own industry - the effective level of concentration for this purpose is greater than merely counting the number of actual decision makers would imply. Greater concentration increases the likelihood that purely random factors will affect market outcomes, and similarly increases the likely magnitude of whatever purely random effects do occur (that is, the volatility of market prices). 7

To a large extent, the potential effects of changing share ownership patterns considered here stem from either or both of these two basic channels.

\section{Providing Capital to Emerging Companies}

The most important single question raised by the changing pattern of share ownership in the United States in recent decades is how it has affected the stock market's ability to provide new capital to successful small companies during their initial period of rapid growth. The issue is central to the market's function of supporting capital formation and entrepreneurship, not only because of the role of small companies as an engine of economic growth but also because of these companies' dependence on external sources of equity financing.

The special contribution of small firms is sometimes difficult to appreciate in retrospect, in part because the most successful small firms often grow over time into large ones, and in part because large firms often maintain their own growth by acquiring successful small ones. But in fact smaller firms do play a large (some argue a disproportionately large) role in job creation as well as in technological innovation in the American economy. ${ }^{8}$ At the same 
time, small firms that are just entering the acceleration phase of their business growth usually need new sources of equity financing. Their growth is too advanced for whatever funds their initial backers provided to continue to suffice, but not yet advanced enough to generate adequate funding internally, or to warrant 1008 debt financing at the margin of new expansion. External equity is necessary.

Can the stock market provide it? To be sure, the incredible ability to support new business development in the United States has traditionally been a distinguishing strength of the American economy. For purposes of the discussion here, however, the relevant question is whether that ability is reduced or enhanced over time by such changes as the progressive institutionalization of share ownership.

On the surface, there seems little reason for concern. The pace of new business formation has continued to increase, decade after decade, throughout the post World War II period. ${ }^{9}$ Within the most recent years, the market for initial public offerings of stock has supported some hundreds of new offerings annually, involving tens of billions of dollars of new equity capital raised. (The market average for 1986-94 was 502 new offerings, totaling $\$ 35$ billion, per year. ${ }^{10}$ ) In addition to the public equity market, the venture capital industry has also continued to grow, with ever more sources of capital provided by investors like pension funds and endowments that had previously restricted their portfolios to more traditional investments. Because such investors often commit funds to privately structured investments largely in the expectation that these assets will become liquid when the company's shares become publicly traded (at which time the initial investors may choose whether to sell or hold), the vitality of the venture capital business is a further reflection of 
confidence in the ability of the stock market to absorb the securities of new small firms.

Concerns along these lines therefore take more subtle forms. One frequently expressed fear is that institutional investors, which compete among one another for the business of ultimate savers, systematically adopt a time horizon that is too short -- in other words, a discount rate that is too high -. to reflect the underlying preferences that individuals would exhibit on their own. 11 Because most new businesses fall, and because those that succeed typically become profitable only after some years, financing small new companies requires patient capital. And there are plausible reasons for thinking that institutional capital, managed by agents in place of principals, is less patient than individuals' own capital.

The rebuttal to this line of argument is that professional managers are not less patient, just better informed. It may now be more difficult to distribute certain kinds of new securities because there are fewer individual investors picking up the telephone to listen when the broker explains the latest new "story" stock, but perhaps those kinds of securities should be more difficult to sell. After all, an investment with expected present value that is negative with a high discount rate but positive with a low discount rate is different from an investment that has negative expected present value under any discount rate at all. (The role of venture capital is especially important in this context. Historically, genuinely new start-ups that have been financed in the public market from their very beginning have often amounted to little more than scams. Legitimate enterprises have more typically relied on private financing at the start-up phase, turning to the public market only after they have established enough of a track record to provide a sufficient basis for evaluation.) 
An alternative form of concern that progressive institutionalization may be depriving worthwhile new companies of financing stems from the increased concentration of decision making that the institutionalization of share ownership implies. Magellan Fund may own 900 stocks, and may participate in numerous IPOs, but how many other fund managers then buy the stock at least in part because Magellan has bought it? If many managers do invest in this way, then the market in its institutionalized state allocates the capital available for new companies to fewer firms than individual investors would have chosen on their own -- and not just because the individuals would have chosen unwisely.

This tendency to focus on a smaller universe of companies draws reinforcement from the legal and regulatory requirements that professional money managers face as fiduciaries. An individual is perfectly free to purchase a stock on the basis of a single call from a broker, but most money managers need to establish their due diligence by relying on research reports prepared by analysts employed either in their own firms or, at the least, at brokerage firms with whom they do business. Managers of some kinds of funds must also restrict their holdings to securities that can be readily priced on a regular basis, in many cases daily. 12

The rebuttal to this second line of argument is that the number of money managers is large and increasing and, moreover, that the extent of "herd" behavior that they exhibit is greatly exaggerated. The money management business in the United State becoming increasingly specialized. Not only do mutual fund companies sponsor vehicles specifically devoted to investment in small capitalization stocks, or even small-cap growth stocks, but most institutional firms seeking to attract pension assets offer to manage separate accounts along just these kinds of lines. (In recent years, the development of 
this form of institutional money management has gained added momentum from the economic forces driving pension assets away from guaranteed income contracts.)

There is also reason to believe that competition among money managers may continually drive portfolios into new outlets for funds. Among mutual funds, cash flow seems to go disproportionately to the more innovative funds, especially in a strong market (the time when most new companies seek to finance). Among managers of pension assets, finding new investment outlets is a useful competitive device as it becomes ever harder to manage conventional stock portfolios so as to outperform standard benchmarks like the S\&P 500. As for research, reporting on new, smaller companies is clearly a large part of what many of the country's smaller or regional brokerage firms do to compete for business. What is not well established in this regard is the relative strength of the effect of such research in directing patterns of institutional trading and share holding, as opposed to the effect of existing trading activity and ownership in directing what research these firms choose to do.

In sum, the argument over whether increasingly institutionalized share ownership has helped or hurt the market's ability to finance new, small firms is not clear cut. Both the preference-based argument (shorter horizons for institutional funds) and the argument based on centralized decision making (greater focus on a smaller universe) have plausible foundations. But so do the counter-arguments. What is necessary to resolve the question is serious quantitative research involving some well-specified counter-factual alternative - for example, whether the recent IPO volume of $\$ 35$ billion per year would have been larger, or the number of deals greater, if the market were still 758 individual. 
III. Institutionalization and Volatility

A second major source of concern about progressive institutionalization is that the resulting concentration of decision making may render market prices more volatile for purely random reasons. Here the qualitative case is fairly straight forward. The real question is whether the degree of concentration that has taken place, or is likely to occur any time soon, is sufficient to deliver a meaningful increase in volatility.

Because public discussion of stock market volatility has often been unnecessarily confused, it is important to be clear that the problem at issue here is the magnitude of purely random fluctuation in prices, not the size or speed of price movements in general. ${ }^{13}$ when Microsoft fails to receive trademark protection for the "Windows" name, Microsoft's stock should decline immediately. Cushioning, or delaying, the price impact of developments that legitimately affect fundamental values will only impair the market's ability to set relative prices that correctly do their job as signals and incentives. Hence familiar complaints to the effect that advances in information technology have made the stock market more volatile by speeding up the dissemination of new information, or quickening investors' ability to respond to it, are largely beside the point.

The volatility that is harmful is instead the purely random fluctuation that, in a world of incomplete information, inevitably takes place around whatever the fundamental values happen to be. When decisions over what to buy and sell are widely dispersed (in the limit, atomized), non-systematic portfolio changes by specific investors are likely to average out, leaving little impact on market prices. But the law of large numbers works poorly when the numbers involved are not large. The fewer the effective number of decision makers - - effective, in the sense of allowing for interdependent behavior .. 
the more purely random buy or sell decisions by specific investors will move market prices. (In the limit, when there is only one investor, the effect of such randomness is infinite volatility because there is no one else to whom to sell or from whom to buy.) And when market prices move for purely random reasons, the signals and incentives they provide are distorted. Moreover, if the added volatility is not diversifiable, it will also worsen the terms on which savers are willing to commit capital to the equity market in the aggregate.

Given this straightforward logical argument, however, there has been 1ittle evidence of increased stock market volatility except for the 1987 crash. The SEC's "Institutional Investor Study" considered the question as of the late 1960s, and found no real increase in volatility in the wake of the rapid institutionalization of trading (far more than that of share holding) in the prior decade. ${ }^{14}$ Subsequent researchers have mostly concurred.

The crash of October 1987 was another matter, however. The Brady Task Force reported that a large part of the market volume on October 19 was driven by a relatively small number of institutions, all lining up in massive volume to se11. For example, of roughly $\$ 20$ billion in total volume transacted that day, including the cash market and futures, one institution alone sold $\$ 1.3$ billion of stock and another $\$ 700$ million in futures. 15 Such actions are the very essence of the "concentration raises volatility" argument.

A further aspect of the problem on that day in 1987 was that many other institutions responded -- or in many cases attempted to respond, since the trades could not be executed .. when the initial price declines triggered program trades previously designed by "portfolio insurance" schemes. In effect, this "insurance" had created the illusion of liquidity where none really existed. Investors therefore stayed in the market, assuming that they 
could withdraw once prices had turned, rather than begin to withdraw in anticipation of the peak. As a result, the peak was exaggerated, and so was the subsequent decline. This problem is clearly related to institutionalization, but merely in the limited sense that only institutional investors were able to buy portfollo insurance in the first place.

An argument along similar lines, but that assigns somewhat more direct responsibility to institutionalization, concerns the role of mutual funds in the 1987 crash. Some of the biggest sellers on October 19 were mutual funds. They, in turn, were simply responding to redemption instructions they had received from their own share holders, consisting mostly of individuals. The interesting question here is whether the volume and timing of redemption orders differed from what individual investors would have done had they owned portfolios of stocks directly. In short, did the availability of mutual funds create an illusion of liquidity for individuals that was analogous to the illusion of liquidity created for institutions by portfolio insurance? And if so, did it affect their trading in similar ways?

The same question about the role of mutual funds arose again in the aftermath of the devaluation of the Mexican peso in December 1994. As of that month, Morningstar Inc. listed 16 mutual funds, with combined assets of $\$ 3.3$ billion, specialized in investing in Latin American equities. To what extent was the decline in price of Mexican stocks (and those of other "emerging market" countries) greater because investors regarded their holdings of these specialized mutual funds as perfectly liquid, and acted accordingly, even though the securities in which the funds had invested were in many cases highly illiquid? 


\section{Effects of $401-K$ Plins}

Pension plans sponsored by private-sector employers now hold more than one-sixth of all stocks issued in the United States. Until fairly recently, the great majority of these plans adopted a "defined benefit" structure, according to which the payment stream promised to participating beneficiaries on retirement did not depend on the investment performance of the assets set aside to fund the plan's liabilities. Promised pension payments depended on factors specific to the individual participant, like final compensation and years of service, but not on whether the assets in the fund did well or poorly. In effect, the sponsoring employer assumed the risk associated with those investments, benefitting (by having to set aside less earnings) if returns turned out to be high and conversely losing out if returns were low. ${ }^{16}$ (The U.S. Government, acting through the Pension Benefit Guarantee Corporation, insures beneficiaries' claims against such pension plans, but not the financial condition of the plans' corporate sponsors.)

The alternative to a defined benefit pension plan is a "defined contribution" plan, in which the sponsoring employer specifies how much will be put into the plan's fund for each participant during his or her working years, but not the payment stream that the resulting accumulation will deliver on retirement. Under a defined contribution plan, therefore, the beneficiaries .. either individually or collectively -. bear the risk associated with the fund's investments. The sponsoring employer does not. Moreover, because of practical considerations stemming from differences in the compensation and service period of individual participants, a defined contribution plan typically creates not just one aggregate pool of assets but, in effect, a separate account for each participant. Hence plan participants bear the risk associated with the invested assets individually, rather than collectively. The outstanding 
example of this kind of defined contribution plan in the United States has long been the TIAA-CREF system for college professors and employees of many other non-profit organizations.

Changing employment patterns in the United States, including in particular the shift of jobs away from large, heavily unionized employers, has slowed the growth of traditional defined benefit plans in recent years while simultaneously accelerating the growth of defined contribution plans. ${ }^{17}$ In addition, during the first half of the 1980 s, as high asset returns rendered many defined benefit pension plans actuarially over-funded, sponsoring employers terminated their traditional defined benefit pension plans and, in their place, instituted defined contribution plans. These terminations slowed after 1985, as new legislation imposed a tax penalty on excess accumulations that reverted to plan sponsors, and then ceased altogether by 1990 , when the tax penalty rose to $50 z .^{18}$ But in large part because of persistent shifts in patterns of employment, the growth of new pension plans since then has still been mostly in defined contribution plans.

Most of the recent growth in defined contribution plans has been in what are labeled 401-K plans, after the relevant authorizing section of the Revenue Code. New legislation first established 401-K plans in 1978. Today more than 908 of all large employers offer them. More than half of all participants in privately sponsored pension plans are in $401-K$ or other defined contribution plans, and more than $20 z$ of all covered workers are now covered exclusively by 401-K plans. 20 Analysis of just why so many companies are now taking this route (and why other employers, especially state and local governments, are not) is interesting in its own right. 21 For the purposes of this paper, however, the important question is how the growth of $401-\mathrm{K}$ plans, at the 
expense of traditional defined benefit plans, affects the stock market's ability to carry out its key economic functions.

At one level, the rise of $401-K$ plans represents a reversal of the progressive institutionalization that has characterized the U.S. stock market throughout the post-war era. Regulations administered under ERISA by the Department of Labor require that sponsors of $401-\mathrm{K}$ plans offer participants a minimum of three distinct investment vehicles, with "materially different risk and return characteristics," among which to choose in investing the contributions to their accounts. 22 Moreover, in many $401-\mathrm{K}$ plans participants have substantial latitude to reallocate existing accumulations. From the important perspective of who chooses the investment allocation at this level of broad asset categories -. equities, bonds, money market instruments, and so on .. the structure of 401-K plans therefore places the investment decision directly in the hands of individuals.

Initial experience with such plans suggests, however, that these individuals do not much resemble the individual investors whose passing from the scene brokers touting "story stocks" regularly lament. Most employees of private-sector firms are not rich people in any sense. Moreover, in making decisions on their 401-K plans, they are explicitly dealing with their own retirement prospects, and doing so on an individual rather than a collective basis. Because most such people have few other assets, beyond their house and their basic entitlement to Social Security and Medicare (and, of course, their human capital), they are less well positioned to diversify the risks of pension fund investment than are corporations that typically have large amounts of other assets, and of many different kinds.

It is no surprise, therefore, that most participants in $401-\mathrm{K}$ plans allocate their pension fund assets very differently than do the corporate 
sponsors of defined benefit plans. Approximately three-fourths of all $401-\mathrm{K}$ plan participants hold no stocks at all, and less than 48 of participants hold as much as half of their plan assets in stocks. ${ }^{23}$ Because participants with higher compensation have larger plan accumulations, and because these are usually the people most able to assume the risks of stock ownership, the aggregate share of all $401-\mathrm{K}$ plan assets invested in stocks is higher than these facts alone would suggest, at 228. Still, the equity share in the aggregate investment assets of all privately sponsored pension plans, including defined benefit and defined contribution plans together, is more than 508 . There is no readily available evidence on whether $401-\mathrm{K}$ plan participants are willing to invest in more specific equity vehicles, like funds focused on small-cap growth stocks, when they have the opportunity to do so. But the data on their overall stock allocations make the prospect dubious.

The relevant question here, which only time will answer, is whether this extreme conservatism of $401-\mathrm{K}$ asset allocations will persist - - in which case equity capital, both in the aggregate and for small companies, will become more scarce in the U.S. market than it otherwise would have been - - or whether this bias reflects in large part the immaturity of the $401-K$ market itself. Because of differences in the ability to diversify risks across non-pension assets, individuals with average working incomes are highly unlikely ever to match the allocation to stocks (or, even more so, to small-cap stocks) made on average by corporate plan sponsors. But it is possible that, over time, even individuals of average means would respond to the advantage that equities offer (or at least have offered, historically) for long-term purposes like investment for retirement. Indeed, with Americans on average not only living longer but also retiring earlier, even the traditional practice of switching from equities in 
the accumulation phase of a defined contribution plan to fixed-income assets in the pay-out phase may increasingly come under question if historical return relationships persist.

While the growth of $401-\mathrm{K}$ plans returns asset allocation decisions at the gross level to individuals, in other important respects this development is likely to increase the concentration of investment decision making that has characterized the market's progressive institutionalization throughout the post-war period. Individual $401-\mathrm{K}$ plan participants choose what fraction of their plan assets to put in stocks, but the choice of which stocks to buy is still up to a professional manager. Moreover, because of the greater burdens associated with communication and record keeping in defined contribution plans, the management of $401-\mathrm{K}$ plan assets is more concentrated than the management of traditional defined benefit funds. If the few large mutual fund firms that have an established advantage in providing the required servicing continue to attract the bulk of the $401-\mathrm{K}$ business, while $401-\mathrm{K}$ plans continue to generate most of the growth in managed pension assets, then the considerations raised above in connection with the increasing concentration of decision making in the stock market will also become more important over time.

\section{v. Implications for Corporate Governance}

In addition to its basic function of mobilizing capital and establishing relative prices, the stock market in a free enterprise economy also plays a potentially important role in the governance of business corporations whose shares are publicly traded. In principle, the directors who choose corporate managers, and to whom management is responsible, are themselves chosen by share holders. They have both the right and the responsibility to guide management actions. When managers prove to be incompetent or dishonest, or inclined to 
act in their own interest when it runs counter to that of the company, it is the directors' job to replace them. And if the directors themselves are not up to the challenge, then the share holders can replace them via a proxy contest.

In practice, for large publicly held companies, this notional mechanism was largely dormant in modern times until very recently. Indeed, until the mid 1980 s there was little evidence of any active mechanism whatever restricting the behavior of management at most large American corporations. Management was, in effect, responsible to no one. 24

Beginning primarily in the 1980 s, however, the stock market did begin to play a more effective role in American corporate governance -- but not along the lines of the standard story as told above. Instead, the stock market developed a "market for corporate control," in which it was possible to change a corporation's management by buying a controlling interest. 25 In effect, given that directors usually chose to defend managements rather than replace or redirect them, and given the existing onerous proxy regulations, in many cases it was easier to buy a majority of a corporation's shares than to obtain proxies from a majority of share holders.

More recently, directors at an increasing number of corporations have begun to act in ways that more nearly resemble the traditional (but traditionally fictional) account of their responsibilities. The boards of GM, IBM, American Express and some other major firms have even gone so far as to effect precipitate changes in top management. ${ }^{26}$ No doubt part of their reason for doing so was the growing awareness that if they did not do the job themselves, then the stock market, serving as a market for corporate control, would do it for them (in which case they would probably no longer be directors). 
The increasingly institutionalized character of the stock market has clearly played a role in this process. Despite SEC rules that have historically restricted communication among institutional share owners in a publicly held corporation, many investment institutions have become more vocal in expressing their views about the affairs of corporations of which they are major shareholders, and even about the people who manage them. ${ }^{27}$ Moreover, In 1992 the SEC made such efforts less burdensome by ruling that communication among institutional investors was no longer regarded as a form of proxy solicitation requiring an SEC filing. 28

Proxy fights themselves remain hard to win, to be sure, but they would be almost impossible if all the proxies were held by atomistic individual share owners. More importantly, winning control of a corporation by buying a sufficient fraction of its outstanding stock is much easier if major investment institutions have large blocks of shares that they are willing to sell. It is highly doubtful that many of the take-overs of the 1980 s, or the management changes of the early 1990s so far, would have taken place if individuals still held 908 of the typical corporation's stock as they did four decades ago.

In addition to this role that institutional share holders have already played in affecting the governance of American business corporations via management changes, some voices have called for such institutions also to play an enhanced role in the ongoing affairs of companies where no change in ownership or management personnel is contemplated. ${ }^{29}$ Some large pension funds have stated a desire to nominate one or more directors of corporations of which they are major shareholders, or to form groups of investment institutions for this purpose. Others have simply favored enhanced communication between corporate managements and major institutional share holders, without involving the selection of directors. In the other direction, some voices have called 
for a much more extensive system of "relational investing" on the part of major share owning institutions, which would attempt to reproduce some of the benefits (presumably without the drawbacks) of the quite different systems of share ownership and corporate governance in Germany and Japan. 30

No one knows where, if anywhere, such proposals will lead. But it is clear that the institutionalization of the U.S. stock market over time has already given the traditional fiction of responsibility in corporate governance much more factual content than used to be the norm.

\section{Summary of Conclusions}

Throughout the post World War II period, ownership of shares in U.S. corporations has migrated from individuals acting directly on their own account to various kinds of intermediary institutions. Pension funds and mutual funds have been especially important among these growing institutional equity investors. Although some of the specifics have changed from time to time, as of the mid 1990s there is no sign that the overall trend toward institutional rather than individual share ownership has yet run its course.

It is plausible on theoretical grounds to suppose that this shift in share ownership, especially on so large a scale, could affect the market's functioning in any or all of several different ways. In particular, the arguments and evidence surveyed in this paper suggest four such potential changes: (1) Increasing institutional ownership could either enhance or impair the market's ability to provide equity financing for emerging growth companies. (2) Increasing institutional ownership, especially in the form of open-end mutual funds, has probably increased the market's volatility in the context of occasional large price movements. (3) The increasing prevalence of defined contribution (as opposed to defined benefit) pension plans, and 
especially of 401-K plans, has probably resulted in an increased market price of risk. (4) Increasing institutional ownership has facilitated a greater role for shareholders in the governance of U.S. corporate business, and correspondingly reduced the independence of corporate managements. Each of these four effects individually is potentially of substantial significance, not just for the stock market but for long-run U.S. economic performance more broadly. All four together make the continuing evolution of U.S. share ownership a matter of considerable economic importance. 


\section{Footnotes}

*This paper was originally prepared for a conference on "Policy Implications of Stockownership Patterns," sponsored by the New York Stock Exchange and held at the Wharton School of the University of Pennsylvania. It has since been substantially revised. I am grateful to Clare Peeters and Michael Morrell for research assistance; to Andrew Abel, Marshall Blume, Barbara Friedman, Robert Glauber, Samuel Hayes, Richard Ippolito, David Kotok, Ted Ladd, Henry McCance, James Poterba, Mark Roe, James Stone, Ralph Tate, John Turner and several others (who preferred to remain anonymous) for helpful discussions; and to the Harvard Program for Financial Research for research support.

1. Data, here and below, are from the Federal Reserve Board's Flow-of-Funds accounts. For a detailed analysis of these trends, see Blume and Zeldes (1993).

2. See, for example, the data summarized in Poterba (1993).

3. Not surprisingly, the trend toward defined contribution plans has attracted widespread interest. See, for example, Kruse (1991), Gustman and Steinmeyer (1992) and Ippolito (1995). Ippolito in particular has emphasized both the development of $401-\mathrm{K}$ plans (a major focus of attention in this paper) as well as the loss of employment at large unionized firms.

4. The basic point is due to Lintner (1969). See Friedman (1980) for an illustration in the specific context of the growth of pension funds.

5. See Jensen and Meckling (1976).

6. Friend et al. (1970) provided the classic description in the context of modern institutional investors. For a more recent treatment, supported by data on costs of diversification in particular, see Sirri and Tufano (forthcoming). Sirri and Tufano show, for example, that portfolios need to contain 40 or more securities to get (approximately) full advantage of diversification; see especially their Figure 3.5 .

7. Shiller (1984), Scharfstein and Stein (1990), and Lakonishek et al. (1992) have presented models showing how "herd" behavior by investors can exacerbate market volatility. Related analyses of "positive feedback" effects on volatility include Genotte and Leland (1990) and DeLong et al. (1990a).

8. Recent research has cast doubt on the familiar claim that small firms actually play a disproportionately large role in job creation. See, for example, Brown et al. (1990), especially Ch. 3, and Davis et al. (1993).

9. New business incorporations averaged 134,000 per year in the 1950 s, 213,000 in the 1960s, 393,000 in the 1970s, 644,000 in the 1980s and 684,900 during 1991-94. (Data for 1994 are through September only.) of course many new businesses fail, but that is exactly the point. What is needed is risk capital. 
10. Data are from Morgan Stanley \& Co.

11. Recent complaints about "short-termism" in American corporations include Jacobs (1991) and Shiller (1992). See Poterba and Summers (1992) for some confirming evidence.

12. These and related issues are reviewed in Protecting Investors (1992); see especially Ch. 11 .

13. By now there is a rich literature distinguishing random from "fundamental" movements in stock prices. See, for example, Poterba and Summers (1988), De Long et al. (1990b), Hasbrouck (1993), and the many references that these papers cite. The literature surveyed by Leroy (1989) is closely related. Black (1971) concisely stated the distinction between price continuity and market efficiency.

14. See U.S. Securities and Exchange Commission (1971).

15. See Report of the Presidential Commission (1988).

16. The basic distinction of who bears the asset return risk in defined benefit pension plans was first drawn by Bulow and Scholes (1983).

17. See again Kruse (1991), Gustman and Steinmeyer (1992) and Ippolito (1995).

18. In the single peak year 1985,582 plans with 709,000 participants underwent such terminations with reversion. Of the $\$ 13.6$ billion of assets held in these plans, $\$ 7.5$ billion went to fund participants' benefits and $\$ 6.1$ billion reverted to the plan sponsors (data are from the Pension Benefit Guarantee Corporation's 1988 Annual Report). For analyses of these terminations, see Ippolito (1986) and Ippolito and James (1992).

19. Schieber and Shoven (1994) have projected that the entire private pension system, including defined benefit and defined contribution plans, will exhibit negative saving in real (inflation-adjusted) terms beginning in 2025 and in nominal terms beginning in 2052. Under current trends, these changes will occur much sooner for the defined benefit sector only.

20. See Employee Benefits in Medium and Large Private Establishments, 1993 (1994).

21. See, for example, Kusko et al. (1994), Kruse (1991) and the many references cited in those papers.

22. These regulations, administered under ERISA section $404(\mathrm{c})$, specify conditions that a plan sponsor must meet so as to be relieved of fiduciary responsibility by giving plan participants effective control over plan investments. For a complete description, see the October 13,1992, issue of the Federal Register.

23. Here and below, see Goldstein and Lynton (1992). 
24. Many observers have commented on this apparent vacuum. See, for example, Lowenste in (1991).

25. See, for example, Jensen (1989).

26. See, for example, Ingrassia and White's (1994) account of the GM experience ( $\mathrm{Ch} .12$ ). For a more general perspective by an active participant, see Millstein (forthcoming).

27. The most prominent example so far has been the California Public Employees' Retirement System (CALPERS). See, for example, Heard and Lyons (1994).

28. See Exchange Act Release No. 34-31326 revising SEC Rule 14A (October 16, 1992): "The amendments eliminate unnecessary regulatory obstacles to the exchange of views and opinions by shareholders and others concerning management performance initiatives presented for a vote of shareholders" (57 Federal Register 48,276).

29. Coffee et al. (forthcoming) includes a number of papers arguing along these lines. See also, again, Lowenstein (1991).

30. See again Shiller (1992). 


\section{References}

Black, Fischer. (1971) "Toward A fully Automated Stock Exchange." Financial Analysts Journal, 27 (July-August), 29-44.

Brown, Charles, Hamilton, James, and Medoff, James. (1990) Employers Large and Smal1. Cambridge: Harvard University Press, 1990.

Bulow, Jeremy I., and Scholes, Myron S. (1983) "Who Owns the Assets in a Defined-Benefit Pension Plan?" Bodie and Shoven (eds.), Financlal Aspects of the United States Pension System. Chicago: University of Chicago Press.

Coffee, John C., Gilson, Ronald J., and Lowenstein, Louis. (forthcoming) Meaningful Relationships: Institutional Investors, Relational Investing, and the Future of Corporate Governance. New York: Oxford University Press.

Davis, Steven J., Haltiwanger, John, and Schuh, Scott. (1993) "Small Business and Job Creation: Dissecting the Myth and Reassessing the Facts." Mimeo: NBER.

DeLong, J. Bradford, Shleifer, Andrei, Summers, Lawrence H., and Waldman, Robert J. (1990a) "Positive Feedback Investment Strategies and Destabilizing Rational Speculation." Journal of Finance, 45 (June), $379-395$.

DeLong, J. Bradford, Shleifer, Andrei, Summers, Lawrence H., and Waldman, Robert J. (1990b) "Noise Trader Risk in Financial Markets." Journal of Political Economy, 98 (August), 703-738.

Employee Benefits in Medium and Large Private Establishments, 1993. (1994) Washington: U.S. Department of Labor, Bureau of Labor Statistics Bulletin No. 2456 (November).

Friend, Irwin, Blume, Marshall E., and Crockett, Jean. (1970) Mutual Funds and Other Institutional Investors. New York: Mc-Graw Hill.

Friedman, Benjamin M. (1980) "The Effect of Shifting Wealth Ownership on the Term Structure of Interest Rates." Quarterly Journal of Economics, 94 (May), 567-590.

Gennotte, Gerard, and Leland, Hayne. (1990) "Market Liquidity, Hedging, and Crashes." American Economic Review, 80 (December), 999-1021.

Goldstein, Michael L., and Lynton, Lili. (1992) The Future of the Money Management Industry. New York: Sanford C. Bernstein \& Co., Inc.

Gustman, Alan L., and Steinmeyer, Thomas L. (1992). Defined Contribution Plans: Fact or Fiction?" Industrial Relations, 31 (Spring), $361-369$. 
Hasbrouck, Joel. (1993) "Assessing the Quality of a Securities Market: A New Approach to Transactions-Cost Measurement." Review of Financial studies, 6 (No. 1), 191-212.

Heard, James E., and Lyons, Jill. (1994) "Institutional Investors: Labor Unions and Public Funds Set Active Shareholder Agenda for 1995." Insights, 8 (December), 3-7.

Ingrassia, Paul, and White, Joseph P. (1994) Comeback: The Fall and Rise of the American Automobile Industry. New York: Simon and Schuster.

Ippolito, Richard A. (1986) "Pension Terminations for Reversion." Journal of Pension Planning and Compliance, 12 (Fal1), 221-242.

Ippolito, Richard A. (1995) "Toward Explaining the Growth of Defined Contribution Plans." Industrial Relations, 34 (January), 1-20.

Ippolito, Richard A., and James, William H., (1992) "LBOs, Reversions and Implicit Contracts." Journal of Finance, 47 (March), 139-167.

Jacobs, Michael. (1991) Short-Term America: The Causes and Cures of Our Business Myopia. Boston: Harvard Business School Press, 1991.

Jensen, Michael C. (1989) "Eclipse of the Public Corporation." Harvard Business Review, 67 (September/October), 61-74.

Jensen, Michael C., and Meckling, William H. (1976) "Theory of the Firm: Managerial Behavior, Agency Costs, and Ownership Structure." Journal of Einancial Economics, 3 (October), 305-360.

Kruse, Douglas. (1991) "Pension Substitution in the 1980s: Why the Shift Toward Defined Contribution Pension Plans?" Mimeo: NBER.

Kusko, Andrea L., Poterba, James M., and Wilcox, David W. (1994) "Employee Decisions with Respect to $401(\mathrm{~K})$ Plans: Evidence from Individual-Level Data." Mimeo: NBER.

Lakonishek, Josef, Shleifer, Andrei, and Vishny, Robert W. (1992) "The Impact of Institutional Trading on Stock Prices." Journal of Financial Economics, 32 (August), 23-43.

Leroy, Stephen F. (1989) "Efficient Capital Markets and Martingales." Journal of Economic Literature, 27 (December), 1583-1621.

Lintner, John. (1969) "The Aggregation of Investors' Diverse Judgments and Preferences In Purely Competitive Security Markets." Journal of Elnancial and Quantitative Analysis, 4 (December), 347-400.

Lowenstein, Louis. (1991) Sense and Nonsense in Corporate Finance. Reading: Addison-Wesley Publishing Co. 
Millstein, Ira M. (forthcoming) "Remarks to the Relational Investing Conference." Coffee et al. (eds.), Meaningful Relationships. New York: Oxford University Press.

Poterba, James M. (1993) "The Growth of 401-K Plans: Evidence and Implications." Mimeo: MIT.

Poterba, James M., and Summers, Lawrence H. (1988) "Mean Reversion in Stock Prices: Evidence and Implications." Journal of Financial Economics, 22 (October), $27-60$.

Poterba, James M., and Summers, Lawrence H. (1992) "Time Horizons of American Firms: New Evidence from a Survey of CEOs." Mimeo: Harvard Business School.

Protecting Investors: A Half Century of Investment Company Regulation. Washington: U.S. Securities and Exchange Commission (May).

Report of the Presidential Task Force on Market Mechanisms. (1988) Washington: U.S. Government Printing office.

Scharfstein, David S., and Stein, Jeremy C. (1990) "Herd Behavior and Investment." American Economic Review, 80 (June), 465-479.

Schieber, Sylvester J., and Shoven, John B. (1994) "The Consequences of Population Aging on Private Pension Fund Saving and Asset Markets." Mimeo: Stanford University.

Shiller, Robert J. (1984) "Stock Prices and Social Dynamics." Brookings Papers on Economic Activity (No. 2), 457-498.

Shiller, Robert J. (1992) "Who's Minding the Store? New York: Twentieth Century Fund Press.

Sirri, Erik, and Tufano, Peter. (forthcoming) "The Economics of Pooling." Crane et al. (eds.), The Global Elnancial System: A Functional Approach. Boston: Harvard Business School Press.

U.S. Securities and Exchange Commission. (1971) Institutional Investor Study: Report of the Securities and Exchange Commission. Washington: U.S. Congress (92nd Congress, 1st session), House Doc. No. 92-64. 